\title{
Domestic Tourism in Kenya: Trends, Initiatives and Practices
}

\section{Bonface Odiara Kihima}

\section{(2) OpenEdition \\ 1 Journals}

\section{Electronic version}

URL: https://journals.openedition.org/eastafrica/289

DOI: 10.4000/eastafrica.289

ISSN: 2790-1076

\section{Publisher}

IFRA - Institut Français de Recherche en Afrique

\section{Printed version}

Date of publication: 1 May 2015

Number of pages: 22-39

ISSN: 2071-7245

\section{Electronic reference} eastafrica. 289 


\title{
Domestic Tourism in Kenya: Trends, Initiatives and Practices
}

\author{
Bonface Odiara Kihima ${ }^{1}$
}

Acknowledgements. The researcher is grateful to IFRA (French Institute for Research in Africa) for enabling him to present his work in progress during the IFRA/NMK symposium held in Nairobi in July 2014.

\begin{abstract}
In 1984, the Kenyan government came up with a domestic tourism policy encouraging Kenyan residents to travel locally especially during the low tourism season. Although domestic tourism is supported for a number of other reasons, the central objective was to even out the seasonality pattern thereby preserving jobs year round. However to date it seems this goal has not yet been realised. A key shortfall is the lack of information and implementation of strategies promoting domestic tourism in Kenya. This paper attempts to explore the nature and practice of domestic tourism and how it fits into the standardised international tourism model in Kenya.
\end{abstract}

For many African countries, Kenya included, international arrivals has been the lifeline of the tourism sector. Consequently, domestic tourism has either been ignored or underestimated largely due to the fact that international tourism is an invisible export generating much needed foreign exchange. In such countries, tourism performance is quoted mainly in terms of international arrivals and resultant revenue generated. For example, in Kenya there were 1.5 million international arrivals in 2013 generating Kshs. 96 billion (Government of Kenya, 2014). Such limited statistics highlighting only international arrivals add to the perception that countries such as Kenya are simply host destinations devoid of any vibrant or significant local tourism. This may be true to some extent given that Kenya suffers heavily in the face of travel advisories emanating from key source markets. However, evidence suggests there is potential for domestic tourism within African countries. In South Africa for example, $60 \%$ of the total frequentation to national parks is by residents while $20 \%$ come from other African countries. In the national parks of Mauritius and Nigeria, 40\% and $80 \%$ of the visitors are residents respectively (Lilieholm \& Romney, 2000).

In Kenya, evidence indicates significant growth in domestic tourism. The Kenya National Bureau of Statistics (KNBS) shows that the number of hotel-bed nights by Kenyan residents has increased from 1.57 million in 2008 to 2.79 million in 2012 (Government of Kenya, 2014). However, such an increase in numbers may be partly attributed to better data recording. Thus, during this period Kenya had an average of 2.3 million overnight stays

\footnotetext{
${ }^{1}$ Snr. Lecturer, Tourism and Travel Management, The Technical University of Kenya. Email: odiarab@yahoo.fr
} 
(about $5.9 \%$ of the population) by domestic tourists accounting for $37.59 \%$ of the total bed nights for the same period. This, compared to the 2001-2005 period which stood at an average of 757,400 overnight stays (about $2 \%$ of the population) by domestic tourists (Kenya Institute of Public Policy Research and Analysis, 2009).

While this may suggest a significant role for domestic tourism within African countries, it is certainly a notable paradox that the East African tourism sector is functioning without necessary research support on domestic tourism. Although attempts have been made to describe this tourism segment, it has mainly been with regard to policy (Dieke, 1991; Sindiga, 1996) and isolated case studies (Kieti, Okello \& Wishitemi, 2014). Thus data on Kenya's domestic tourism is still scanty (Ibid.). Consequently little has been documented on domestic tourism practices, trends, and initiatives geared toward understanding the domestic tourism market. Therefore the key research question is: how do the domestic tourism leisure practices fit into the existing standardized tourism model associated with international tourists? The aim is to establish whether Kenya's domestic tourism segment reproduces, appropriates, and modifies existing tourism practices, or if it experiments with totally new paths.

To answer this question, in June 2014 questionnaires were distributed to 30 randomly selected marketing managers of beach hotels and tour companies on Kenya's North and South coasts. Respondents were given 2 weeks to complete the research instrument, and at the time of collection 20 questionnaires had been completed. All of the questions were open ended to enable respondents to reply as they wish and provide extensive answers instead of complying with the researcher (Openheim, 1992 in Yuksel, 2003). A Kenya Tourism Board (KTB) official as well as the Executive officer of Kenya Association of Hotel Keepers and Caterers Mombasa office, were among those who participated in the study. The research therefore adopted a qualitative methodology which tends to capture reality in interaction, studies small number of respondents, tries to approach reality without preconceived ideas and prestructured models and patterns, and aims to understand people and not to measure them (Sarantakos, 2013). The focus is on the how and what rather than why and whether (Finlay \& Ballinger, 2006).

\section{The (in) significant role of domestic tourism}

Domestic tourism in Kenya is an under researched topic. Both undergraduate and graduate levels in Kenyan universities place more emphasis on international tourism or tourism in general. This is evident in the curriculum as well as the various research topics in graduate schools covering different facets of international tourism: consumption patterns, motivations, and service perceptions among others. Out of 100 topics under study by graduate students in the school of hospitality and tourism of Kenyatta University in 2014, only 3 were 
related to domestic tourism. Thus, the potential for Kenya's tourism sector remains unseen and largely undeveloped (Kihima, 2014).

Both professional and policy orientations toward tourism in Kenya has mainly centered around what Kenya has to offer in terms of products and attractions, as well as its enormous untapped potential. For instance the Kenya Institute of Public Policy Research and Analysis (2009), World Bank Group (2010), and Kihima (2010, 2014) show that only a small number of destinations are highly visited (a few national parks and the coast line) while many others are empty or devoid of tourism activities altogether. Thus, in 2013, most visitors preferred to stay at the coastal region which accounted for $45.5 \%$ of the total bed-nights occupancy, while Nairobi region accounted for 24.7\% (Government of Kenya, 2014).

To open up the less visited areas in Kenya, there has been a call for more marketing efforts and infrastructural developments (Kihima, 2014) as well as suggestions to expand the tourism product on offer beyond the "big five" which comprises the elephant, lion, rhino, cheetah, and buffalo (Okello et al., 2008). With such calls, more emphasis has been placed on international rather than domestic tourism as exemplified by the term alternative tourism which rarely refers to domestic tourism. Erroneously, the assumption has always been that domestic tourism is similar to international tourism in most ways except for the participants.

Further to this, Kenya's tourism has typically been externally focused with a bias towards international visitors (Sinclair, 1990; Sindiga, 1996). Odunga (2005) for instance studied the choice of attractions, expenditure, and satisfaction of international tourists to Kenya however such a study has not been done with regard to the domestic tourism market. The official government statistics in Kenya, published yearly by the KNBS, lacks the necessary domestic tourism data. It captures only international arrivals and departures hence failing to show the magnitude of domestic tourism in Kenya outside of bed-nights spent by Kenyan residents in classified hotels.

Consequently, the role of domestic tourism in Kenya remains secondary to international travel, as evidenced by the limited writings on the subject by Kenyan tourism scholars. In the recent past, the Ministry of Tourism Strategic Plan for 2008-2012 identified domestic tourism as one of the ways in which tourism source markets can be diversified while providing a cushion against seasonality. This is not a new assertion given earlier observations by Dieke (1991, p.296): "the government hopes to boost hotel occupancies, and possibly discourage Kenyans not only from taking foreign travel but, perhaps more importantly, make them more appreciative of their country". As a result, the government created a coordinating and monitoring body, the Domestic Tourism Council, to give incentives to local people to travel. Interestingly, during the researchers' interaction with tourism stakeholders at the Kenyan coast, quite a number of them had not heard of such a body. There is therefore need to review performance of the tourism sector institutions in order to justify their very existence. 
Moreover, Kieti, Okello, and Wishitemi (2014) observed that in 2009 the government created the Domestic Tourism Strategy Task force to develop domestic tourism in Kenya and that Kenya's Ministry of Tourism declared the year 2010 the year of domestic tourism with the aim of instilling a holiday culture among Kenyans. The focus on domestic tourism meant that the country should also focus on the domestic market. It brought to the forefront the fact that consumers of the tourism product can also come from within the Kenyan borders; hence the call to create more awareness which could help change the mindset that tourism is only foreign oriented. Despite such efforts it is difficult to measure the achievements since there is no benchmark against which progress can be measured. Indeed, Boniface (2001, p.39) decries the fact that "one perceived problem is the lack of adequate mechanisms in the industry to monitor outcomes of initiatives". The difficulty to judge performance of the industry beyond the year 2010 campaign is a case in point.

Still, much of the domestic tourism debate has limited itself to the easier part of highlighting challenges hindering or facing its development. This includes lack of resources (time and money), limited knowledge on various options available, inaccessible tourism product, and the existing cultural context and perceptual issues (table 1). Indeed, the national tourism policy of 2010 observes that most Kenyan nationals have not been able to participate in tourism due to financial constraints and lack of tourism knowledge, coupled with a paucity of programs and packages. While this may be the first step toward understanding the domestic tourism market, the debate seems to have stagnated at this point. This has done little to help gain insight on domestic tourists with regard to motivation, travel plans, patterns, and how the domestic market can be segmented.

\section{Table 1: Challenges affecting the growth of domestic tourism in Kenya}

\begin{tabular}{|l|l|}
\hline No prior planning for holidays & Lack of saving culture amongst Kenyans \\
\hline Absence of longer holidays for workers & Economic hardship \\
\hline High cost of services & Lack of disposable income \\
\hline $\begin{array}{l}\text { No extensive and well developed } \\
\text { marketing strategy }\end{array}$ & $\begin{array}{l}\text { Cultural factors, notably not being used to } \\
\text { going on holiday }\end{array}$ \\
\hline $\begin{array}{l}\text { Perception that tourism is expensive } \\
\text { Over focus on international markets by and tour operators }\end{array}$ & $\begin{array}{l}\text { Lack of information concerning attractions } \\
\text { and accommodation }\end{array}$ \\
\hline
\end{tabular}

Source: field interviews, 2014 (the challenges are not arranged in any particular order)

Moreover, as argued by Sindiga (1996, p.25), "a system of statistical book-keeping which specifies country of citizenship and region and/or of permanent residence for Kenyans will capture data on the extent and magnitude of domestic tourism". This has never been the 
case to date as shown in fig. 1 where Kenyan citizens are presumed to be in the same group as Kenyan residents. The latter refers to expatriates or members of the diplomatic community working in Kenya - a term that can be confused with Kenyan citizens. Thus data on hotel bed-nights does not purely distinguish Kenyan citizen from residents (Sindiga, 1996). Even the domestic tourism data for Kenyan parks lumps together East African citizens (Uganda and Tanzania and later incorporated Rwanda and Burundi). Due to the aforementioned, it remains therefore difficult to estimate, track, and even measure the extent and magnitude of real domestic tourism in Kenya.

Figure 1: Hotel bed-nights occupancy by country of residence (1998-2012)

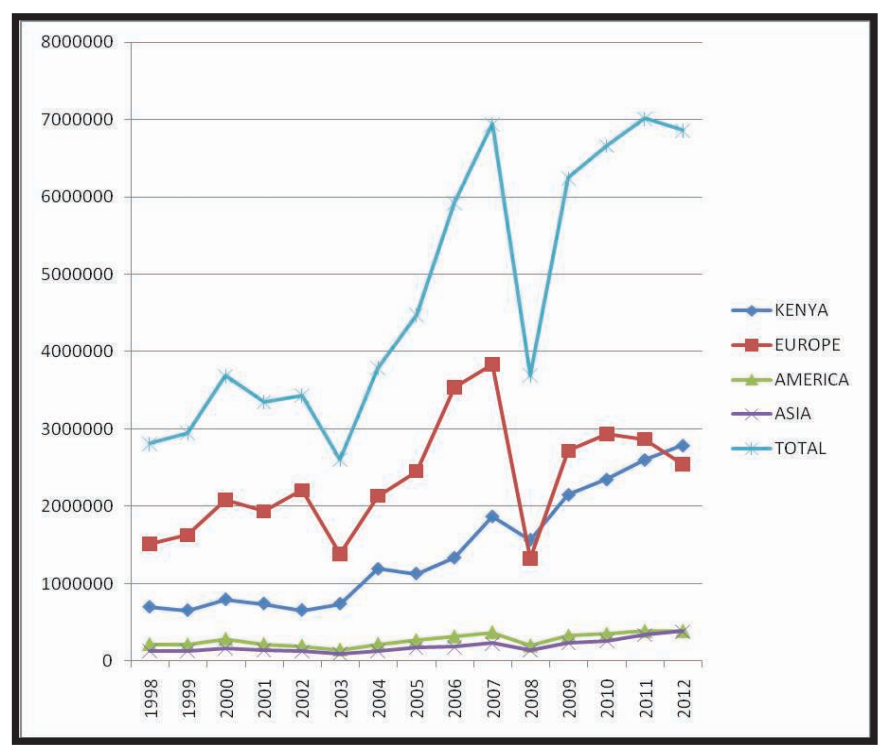

Source: Government of Kenya, 2014

\section{Domestic tourism trends}

Domestic tourism refers to travelling within one's own country for the purpose of leisure or pleasure. It is not a subset of international tourism and should not be conceptualized as an extension of the same. In essence one has the global-local nexus while the other has the local-local orientation. Nevertheless, it should be acknowledged that most domestic tourists frequent the same destinations as international tourists. For instance around $60 \%$ of the bed nights spent by Kenyan residents are in the coastal area and in Nairobi (table 2). In this regard, Kenya Institute of Public Policy Research and Analysis (2009, p.98) observes that "bed nights by domestic tourists in the country are also concentrated in the Coast and in Nairobi. This pattern, which is also similar to that of inbound tourists, is a cause of concern". This shows that domestic tourism may actually be reproducing and appropriating the existing patterns of travel as exemplified by international tourism. 
Table 2: Hotel bed-nights occupied by Kenyan residents - percentage of the total is shown in brackets

\begin{tabular}{|l|l|l|l|l|l|}
\hline & Nairobi & Coast & Lodges & Others & Total \\
\hline $\mathbf{1 9 9 4}$ & 124,300 & 214,100 & 30,100 & 149,800 & 518,300 \\
& $\mathbf{( 2 4 . 0 \% )}$ & $\mathbf{( 4 1 . 3 \% )}$ & $\mathbf{( 5 . 8 \% )}$ & $\mathbf{( 2 8 . 9 \% )}$ & \\
\hline $\mathbf{2 0 0 2}$ & 120,300 & 325,800 & 18,500 & 191,500 & 656,100 \\
& $\mathbf{( 1 8 . 3 \% )}$ & $\mathbf{( 4 9 . 7 \% )}$ & $\mathbf{( 2 . 8 \% )}$ & $\mathbf{( 2 9 . 2 \% )}$ & \\
\hline $\mathbf{2 0 1 2}$ & 532,800 & $1,106,500$ & 95,100 & $1,053,300$ & $2,787,700$ \\
& $\mathbf{( 1 9 . 1 \% )}$ & $\mathbf{( 3 9 . 7 \% )}$ & $\mathbf{( 3 . 4 \% )}$ & $\mathbf{( 3 7 . 8 \% )}$ & \\
\hline
\end{tabular}

Source: Government of Kenya, 2014

This therefore informs the assumption that domestic tourists share an interest in the same destinations as international clients. For instance, a World Bank Group report (2010, p.63) noted that "when international, long-haul visitors are less inclined to travel to Kenya, domestic and intra-Africa visitors can fill hotels and safari vehicles". On its part, Kenya Institute of Public Policy Research and Analysis (2009, p.96) stated that, "Domestic tourists could greatly help reduce seasonal fluctuations of overnight stays, especially in periods of negative travel advisories". One may therefore wonder if this is normally the case given the turbulent times the Kenyan tourism sector has faced. Essentially, the domestic market is seen as a stopgap measure when international arrivals are not forthcoming; as a panacea for the struggling industry rather than as a significant market segment.

The filling up of hotels and safari vehicles may not really be the case since the domestic tourism cycle takes place almost in the peak season of international tourism. The Kenyan cycle revolves around the school holiday calendar in April, August, and December when many would like to travel as families or school groups. This may be different from the traditional high season for international tourists that starts in June and ends in August as well as November to January. However, using the example of marine parks at the Kenyan coast, it can be shown that, with the exception of the month of April, the domestic high season overlaps with that of the international high season (fig. 2). The implication is that during the high season, services are normally constrained and may largely discourage the domestic traveller who may have the perception of being ignored and subordinated to the international tourist, or even discriminated against.

Figure 2: Average number of visitors in Kenyan marine parks per month 2006-2012 


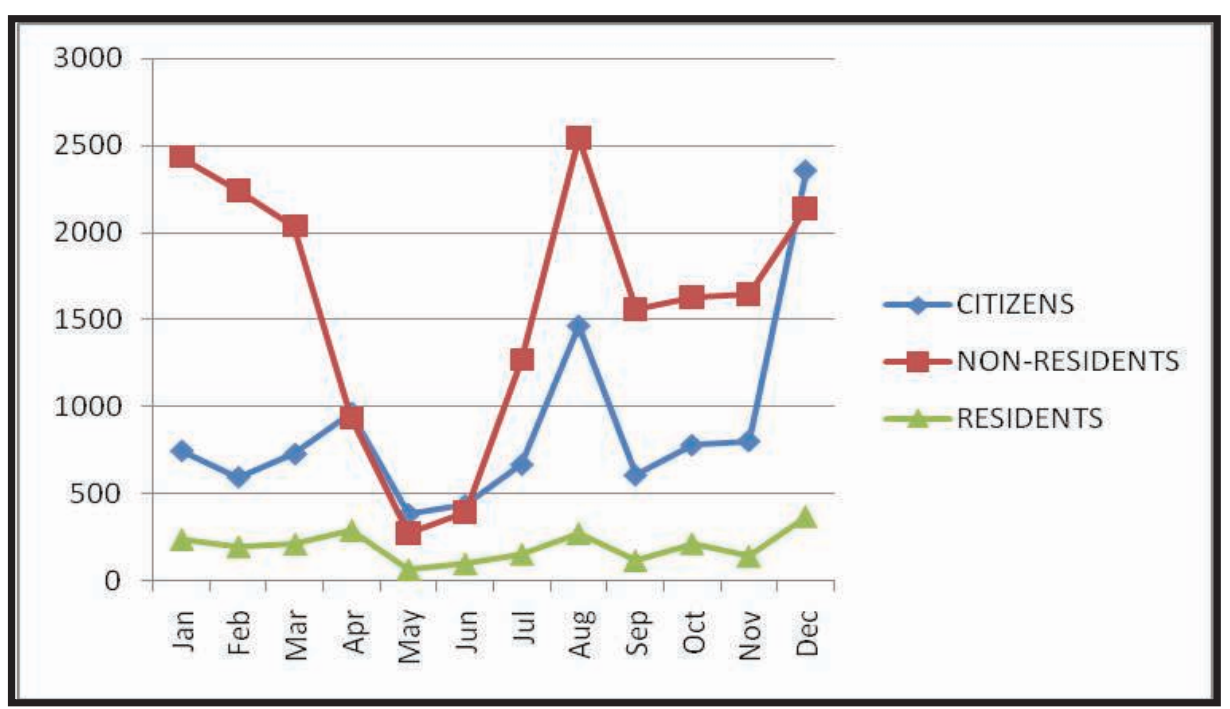

Source: Kenya Wildlife Service data office, 2014 (personal communication)

Except for the local corporate client or business traveller who visits such establishments during the low season, it can be concluded that these two tourisms (domestic and international) are actually in competition rather than complementing each other as evidenced by the closing down of some hotels at the Kenyan south coast during the low season for lack of visitors. Nevertheless, according to KTB (personal communication), domestic tourism in Kenya accounts for $43 \%$ of total tourism revenues. This substantial percentage may be attributed to the growth in MICE (meetings, incentives, conventions, and events) sector (table 3) that still has a great but unrealized potential attributed to the number of delegate days available. 
Table 3: Number of conferences 2010-2012

\begin{tabular}{|c|c|c|c|c|c|c|}
\hline & \multicolumn{2}{|l|}{2010} & \multicolumn{2}{|l|}{2011} & \multicolumn{2}{|l|}{2012} \\
\hline & Local & International & Local & International & Local & International \\
\hline Number & 2,529 & 254 & 2,995 & 309 & 3,338 & 328 \\
\hline Delegates & 383,441 & 30,554 & 408,596 & 33,566 & 413,637 & 35,663 \\
\hline $\begin{array}{l}\text { Delegate } \\
\text { days }\end{array}$ & 467,781 & 153,081 & 497,523 & 197,562 & 554,443 & 209,910 \\
\hline $\begin{array}{l}\text { No of } \\
\text { delegate days } \\
\text { available }\end{array}$ & $5,368,174$ & $5,368,174$ & $5,520,344$ & $5,520,344$ & $5,652,611$ & $5,652,611$ \\
\hline $\begin{array}{l}\text { \% } \\
\text { occupancy }\end{array}$ & 8.7 & 2.9 & 9.0 & 3.6 & 9.8 & 3.7 \\
\hline
\end{tabular}

Source: Government of Kenya, 2014

Compared to developed nations, domestic tourism seems to be of a greater magnitude because of a tourism culture in which residents travel at least once a year beginning with their countries. Such are referred to as experienced tourists who largely pre-plan their travel (Odunga, 2005). This is due to many obvious factors that enhance tourism including ability (time and money), mobility, motivation, and even government initiatives aimed at social tourism. According to Pierret (2011), United Nations World Tourism Organisation's (UNWTO) economists estimate that at the global level domestic tourism represents $73 \%$ of total overnights: $74 \%$ of arrivals and $69 \%$ of overnights at hotels; $89 \%$ of arrivals and $75 \%$ of overnights in other (non-hotel) accommodations.

\section{Kenyan domestic tourist}

In 2012, Europe was the largest source market for Kenyan tourism accounting for $57.9 \%$ of total international tourist arrivals, followed by Africa with $16.9 \%$, North America $11.8 \%$, and Asia 10\% (Government of Kenya, 2012). Statistics indicate that Kenya's tourism sector is currently largely hinged on international tourist arrivals which account for $70 \%$ of the country's total tourism, while domestic tourism accounts for the remaining 30\% (Kenya Tourism Federation, 2010). 
The contrast between international and local tourism is evident. For the potential local tourist, there are many competing interests in life: the need to go to school, servicing of mortgages etc leaving little or no savings for travel purposes. In many African countries exists, instead, a culture of survival whereby the idea of travel is considered a luxury that many people cannot afford or they take such activities for granted. For instance Boniface (2001, p.11) observed that "One common element in all tourism is that it is engaged in only a discretionary basis, to serve higher needs, such as self-fulfilment and spiritual enrichment. Tourism is not a basic survival necessity". In Kenya for instance, a paltry 2.2 million people in modern wage employment, out of a total population of 39.5, earn an annual wage of about Ksh. 432,802. This translates into Ksh. 36,066 per month (Government of Kenya, 2012).

More recently however, though survival is still a factor, several factors are beginning to change the existing scenario and the interest in domestic tourism is growing. This has been attributed to the appreciation of domestic tourism as an effective means to enhance stabilized revenue flows in low seasons, of enhancing inter-ethnic dialogue, a means of transferring wealth and investment from the developed regions to the less developed areas, and a means to keep the hotels open throughout the low season (something that it has failed to accomplish) among others.

To understand the domestic traveller in Kenya, an open-ended question was posed to tourism stakeholders to describe the Kenyan domestic tourist. The varied answers to this question are shown below (table 4).

\section{Table 4: Description given to the Kenyan domestic tourist}

\begin{tabular}{|c|c|}
\hline Vibrant and has a lot of potential & Travels during festive seasons \\
\hline Prefers short stays & $\begin{array}{l}\text { Prefers to stay in hotels other than camps } \\
\text { when visiting national parks }\end{array}$ \\
\hline Has not valued tourism yet & Has the potential but is uninformed \\
\hline Needs encouragement & He is a major income earner in tourism today \\
\hline $\begin{array}{l}\text { Seeks experiences that rejuvenate and } \\
\text { teach }\end{array}$ & $\begin{array}{l}\text { Does not explore touristic destinations } \\
\text { expansively }\end{array}$ \\
\hline
\end{tabular}

Source: field survey, 2014

In essence, domestic tourists are rather last minute oriented and more spontaneous in the kind of activities they choose, hence more difficult to plan for. Nevertheless, it is easier to predict this market's travel schedule (peak season), unlike the volatile nature of international tourism due to other external factors. The domestic client is socially oriented rather than activity based, desiring experiences in a group. However, many lean more towards psycho- 
centrism as evidenced by their search for symbols of home like food and drinks rather than being adventuresome. For instance, those who travel from Nairobi to the Kenyan coast for hedonism end up doing the same activities they would have otherwise done in Nairobi. In other words they change the usual environment momentarily without much change in the activities: shopping, alcohol, roasted meat, and clubbing. While an international tourist may feel safe and secure within the tourist ghettos and enclaves, his Kenyan counterpart will find such an environment to be boring, encouraging them to venture out to find freedom and mingle with other Kenyans in night clubs, shopping malls, restaurants, pubs, and other entertainment spots.

Moreover, the domestic tourist spends less on other services associated with what they have already purchased - massage, buying of souvenirs, tour guiding services etc. Being cost conscious, little or no money is spent on other services deemed unnecessary apart from key services e.g. transfers back to the airport/hotel. However, more is spent on food and beverages than on excursions suggesting that such a client actually arrives lacking the motivation to explore the destination extensively. Instead, the domestic client makes shorter stays and usually visits a particular place for a particular reason. A case in point is the domestic conference tourist who stayed on average of 0.9 days between 2010 and 2012 while the international delegate stayed for 5.6 days on average (table 3).

Having less purchasing power, the domestic tourism practices are therefore defined to a large extent by price and accessibility. For instance a study done in Mtwapa area, North Coast, established that non-classified hotels in Mtwapa town received most of their guests (81.7\%) from within Kenya (Kivuva, Kihima and Nzioka, 2014). This could be attributed to the fact that the hotels are of lower standards, and are price friendly to the domestic market. Thus, Pierret (2011) noted that the domestic traveller seeks the best price-quality ratio, or often the lowest possible price, in all segments of the tourism value chain: accommodation, food services, tourism activities, shopping, etc. This means that the domestic traveller is likely to use local services and products: home stays, local guesthouses, lodgings, local foods, and local photographers, with the exception of buying souvenirs. This may be one way of diffusing tourism activity among local entrepreneurs albeit to a smaller level.

In essence, destination organization is largely informed by the international tourism demand. Thus, the international tourist has compelled the investor to offer what they want (infrastructure, food, language, marketing messages...). Being an invisible client due to their travel behaviour such as the use of own transport, the domestic traveller remains an overlooked client having distinct attributes as shown below (table 6). 
Table 6: attributes of the domestic leisure/family holiday maker

\begin{tabular}{|l|l|}
\hline Spends more on drinks & Prefers full board package \\
\hline $\begin{array}{l}\text { Less savvy and easy going on food } \\
\text { and service expectation }\end{array}$ & $\begin{array}{l}\text { Drinks and eats a lot hence very expensive to keep } \\
\text { if on all inclusive and full board }\end{array}$ \\
\hline Prefers local cuisine & Less adventuresome \\
\hline Prefers hotels with strong animation & $\begin{array}{l}\text { Purchase for holiday driven by celebration and } \\
\text { family fun time }\end{array}$ \\
\hline $\begin{array}{l}\text { Spends more time in the restaurant } \\
\text { and are not sensitive to time }\end{array}$ & Prefers attention and personal recognition \\
\hline
\end{tabular}

Source: field survey, 2014

\section{Domestic Tourist in a Leisure Setting}

Tourism is about the freedom to explore beyond one's usual area of residence. It is about going somewhere away from home. However, the majority of Kenyans exercise this freedom in their own backyards by engaging in passive leisure activities and home based tourism actions which includes visiting friends and relatives, roots tourism, or practicing tourism related activities in one's own home environment. Such include participating in leisure activities within driving distance while sleeping in one's own bed at night. Pierret (2011) rightfully observed that domestic tourism is practiced more in a sedentary (staying in the same place) than a nomadic manner. This is where the majority of Kenyan domestic tourists' recreational sites such as beaches, Nairobi safari walk, urban parks, and museums fall. This may be the starting point in developing domestic tourism with the need to inculcate outdoor recreation in the Kenyans' mind. Once one has explored their own backyard extensively, then they are able to move elsewhere in search of new experiences.

Assuming that the leisure pursuits of the local population are a reflection of domestic tourism practices, it can be concluded that, in the absence of the tourist culture, the domestic tourist is likely to contend with basic tourist infrastructure due to lack of prior experience and exposure. With this, it is therefore possible to extend the tourism offer beyond the traditional tourism destinations since they have a greater tolerance for basic services. This is not to say that quality is not a factor for the domestic clients but it shows that with a minimum service requirement, it may be easier to satisfy and handle the domestic tourist. For instance, in areas such as the beaches, day time domestic tourists are not so distracted by lack of essential amenities like toilets, shower tabs, and appropriate changing rooms among other services. They may not really see anything wrong with recreating alongside litter. 
In addition, there seems to be a clear dichotomy between the domestic traveller and the international tourist. Along the sea front, African populations mostly congregate above the high water mark clearly shunning the beach (sun and sand) while a few will be in the water (sea). Many adult Kenyans frequent these places preferring to be inactive rather than participate in recreational activities such as water sports, which confirm our assertion that they have not yet embraced the tourism culture. They prefer to shelter themselves away from the hot sun while gazing into the horizon. Those of Arabic and Asian decent often travel with their own vehicles to the beach (e.g. Nyali and Mama Ngina) in groups of three or four but hardly leave the vehicles and may be spotted listening to music, eating their own packed food, while some spend their time chewing miraa. One notable absence on the beach for the Kenyan population is the lack of sunbathing activity. Few people, especially adult women, can be spotted wearing beach attire as the majority prefer to be fully dressed. Moreover, while it may be easier to identify a foreign tourist: by skin colour, clothing, carrying of brochures, maps and cameras, walking in groups, and having a tour guide by their side, the same may not be easily said of a local tourist who blends into the environment; the domestic tourist does not easily stand out from the crowd.

\section{Setting the pace for the tourism sector?}

It can be argued that adoption of the Western tourism model (photographic safari, and coastal vacations) has reduced domestic tourism to a subset of the larger conventional tourism system supported by the international market. Many local tourists also visit the same places frequented by foreign tourists - terrestrial and marine parks etc. Sindiga (1996, p.26) rightfully observed that "perhaps one of the weaknesses of Kenya's domestic tourism is the tacit policy to have Kenyans go to the same facilities and places visited by overseas tourists". Thus, geographically speaking, the domestic tourism model fits into the international model mainly due to the infrastructural setup of the sector. This has greatly contributed to crowding in touristic destinations and constrained the tourism offer. Therefore, the question to ask is: who actually is setting the pace for tourism practices in the country - domestic or international tourist?

To answer this question, it is important to look at the Kenyan tourism sector organization. Indeed, traditionally travel intermediaries have played a pivotal role in destination management. With $80 \%$ of the tourists to Kenya buying packaged tours (Odunga, 2005), the tour operators play a key role in determining tourism practices and destinations. But with domestic tourists travelling independently, it is possible that they can introduce and sustain new tourism practices in the country, albeit to a lesser level. What is evident, however, is that it tends to trail the international tourism trends and practices. For instance, many Kenyan University and College students' travel activities tend to follow international tourism 
patterns: Nairobi, Nakuru, Maasai Mara, Amboseli, Tsavo, and the coastal part of the country. Still, just like international tourism, there is also minimal frequentation to museums and other cultural sites by Kenyan adults as evidenced in table 7.

Table 7: Tourist Flow to Kaya Kinondo: an ecotourism site owned by the local community in south coast, Kenya (2009-2011)

\begin{tabular}{|l|l|l|l|l|}
\hline Year & Students & Kenyan citizens & International tourists & Total per year \\
\hline 2009 & 359 & 67 & 454 & 880 \\
\hline 2010 & 628 & 128 & 610 & 1,366 \\
\hline 2011 & 344 & 71 & 850 & 1,265 \\
\hline
\end{tabular}

Source: Kihima and Kimaru (2013)

It must be recognized that domestic tourism in Kenya is still at inception stages. Greater geographical dispersion of tourists can be aided by the impact of car ownership, allowing people beyond the parameters of fixed modes of transport. Most Kenyan parks are remotely located requiring one to have a self driven vehicle or to rely on a tour van to access them. In Kenya, this may still be a challenge. For instance in 2011, the number of motor cars (personal vehicles) in Kenya is estimated to be 598,622 with approximately 40,000 new vehicles being added to the roads yearly (Government of Kenya, 2010). This may not be a substantial number to warrant mass domestic tourism in the country. According to World Bank, there were 14 passenger cars in Kenya per 1000 people compared to 482 in France in 2011. This includes road motor vehicles, other than two-wheelers, intended for the carriage of passengers and designed to seat no more than nine people including the driver (World Bank, 2010).

In the commercial sector, Sindiga (1996) noted that there are no prescribed buses to cater for domestic tourists who would wish to visit National Parks or Reserves. Some Tour operators sampled for this research indicated that they do not target domestic tourists at all so could not participate in the study. In addition, many of the domestic tourism safaris advertised beginning and ending their journey in Nairobi (Kieti et al., 2014) which may easily exclude many local tourists wanting to participate in different forms of tours.

\section{Initiatives to promote domestic tourism}

Through the twende tujivinjari (lets go have fun), the Tembea Kenya (explore Kenya) initiatives, domestic tourism is being promoted as the next frontier to boost the much needed tourism revenues in Kenya. Kenya Wildlife Service (KWS) has also maintained low conservation (park entry) fees for Kenyan citizens. For instance, to access the premium parks 
of Lake Nakuru and Amboseli, a citizen pays Kshs. 1000 (US \$11) while a non-resident pays US \$80. The KWS has also encouraged domestic travel through the provision of a bus and guided visits to the Nairobi and Lake Nakuru National Parks every weekend including public holidays to encourage Kenyans to take part in tourism. Moreover, the members of WCK (Wildlife Clubs of Kenya), especially those who are in Kenyan educational establishments, can visit premium national parks at very subsidized rates for Kshs. 200 (US \$2). In the case of Kenyan marine parks, it can be shown that a third of total visitations between 2006 and 2012 were by Kenyan citizens, and $60 \%$ by non-residents (fig. 3). In general, domestic tourism flow to KWS protected areas accounted for 44\% of the total visitation in 2008 (Kihima, 2010).

\section{Figure 3: Average marine park visitation 2006-2012}

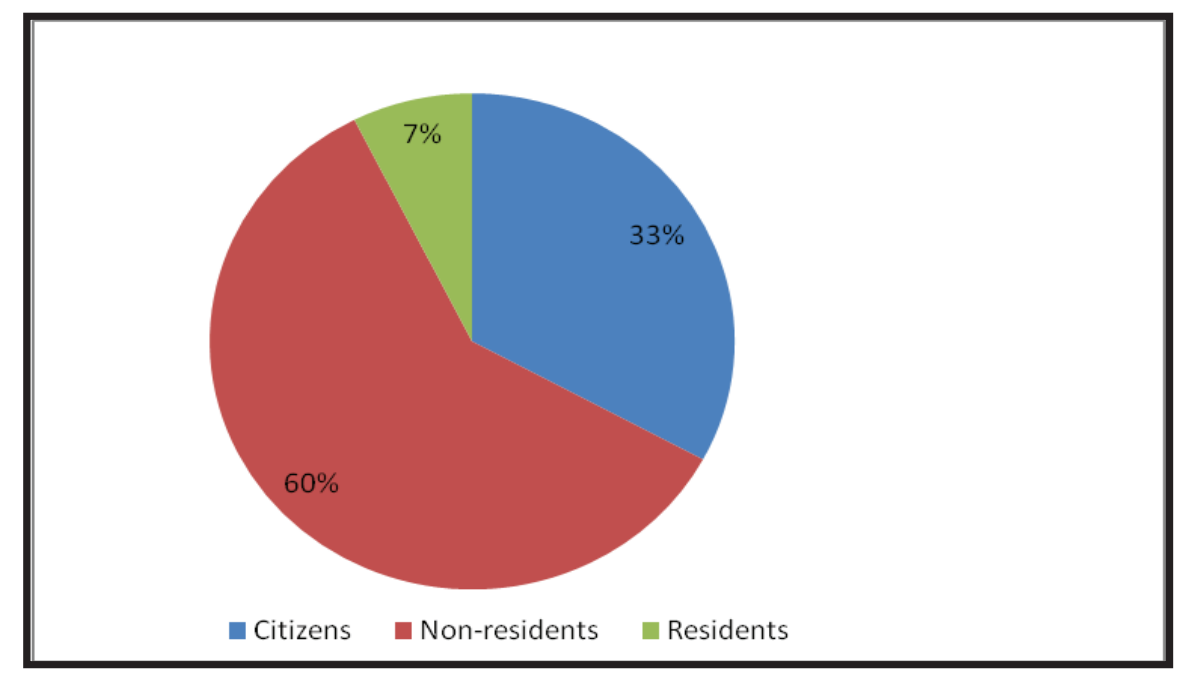

Source: Kenya Wildlife Service data office, 2014 (personal communication)

For the National Park frequentation, the only downside lies in the fact that the national market does not generate enough income for the protected areas. The direct economic impact generated by domestic tourism is indeed insignificant in terms of the conservation fee. Thus, in spite of the fact that $50 \%$ of the tourists to Lake Nakuru National Park were Kenyans between 2000 and 2004, they only contributed 5\% of the total income for the same period for KWS. In Amboseli and Aberdare National Parks, Kenyans constituted 25\% and 19\% respectively of the total visitation. However, in terms of revenue this market segment contributed only 1\% in for each one of these parks (World Resource Institute et al., 2007). This is not to diminish the significance of domestic tourism, but to illustrate the importance of international tourism in financially supporting protected areas of the country. Despite these facts, Akama (1997) and World Tourism Organization (2012) observed that domestic tourism may have a greater impact on local economies and local development whereby they are more likely to buy from local vendors than foreign tourists. Future research should be done on the 
contribution of domestic tourism to the accommodation sector. Pierret (2011) noted that knowledge and proximity of the destination, and lower cost of transport for domestic tourists, brings about an entirely new series of consequences. This includes but is not limited to involvement of all social strata, from the wealthiest to more modest (but stable) incomes; giving rise to a large diversity in demand in terms of accommodation and tourism products as well as activities and destinations. However, the unit expenditure is markedly lower than in international tourism, especially interregional tourism, but the overall volume of expenditure remains higher.

\section{Bringing Attractions Closer to the People}

It should be acknowledged that what fuels tourism activity is not uniformity, but differences, contrasts, otherness, novelty, and fresh experiences (Boniface, 2001). The branding of Kenyan parks has exposed the diversity of Kenya's tourism industry and the various opportunities that local people as well as international tourists may enjoy while visiting the country (Kihima, 2014). Through this the KWS has shown that indeed attractions are not just over there but they are here as well - in our backyards. The various tourism practices and experiences are explicitly announced through various taglines proposed for the national parks (Kihima, 2014). A case in point is the Kisumu Impala which announces the fact that visitors can take "A Lake Shore Walk with the Impalas"; Mt. Kenya asks the visitors to "come touch the sky"; while in Ndere Island visitors are promised the "Island of Serenity and Beauty".

With such diversity as exemplified by the branding messages, hope for the Kenyan tourism industry may come via inexperienced domestic tourists fascinated by the zebra fish of Malindi, the Sitatunga of Saiwa, and the Roan Antelope of Ruma. This inexperienced tourist may still be a stranger to various landscapes, flora, and fauna, and may easily find them fascinating. Indeed, domestic tourism can serve to launch a destination (Pierret, 2011). This may form a good starting point to popularize the undeveloped sites. Thus, while "Europeans want to see the Africans and the African landscape in the same way as they were taught to see them during their formative years of image-moulding" (Wels, 2000, p.64); the local tourist has no such background information. For the international traveller, the images of safari, big five, savanna, and Maasai are still persistent (Kihima, 2014). Europeans, according to Wels (2000, p.64), "long for pristine African Landscapes with picturesque thatched roofs dotted and blended into it and expect to hear drums the minute they arrive in Africa."

While the micro-fauna may not really be appealing to the international tourist who may have been promised spectacular attractions like the wildebeest migration, the absence of such a promise to the domestic tourist can make his visit fulfilling irrespective of the destination. Boniface (2001, p.127) noted that: "Old products may have a current life in exactly their old 
role. After suffering a downturn and falling out of tune with tourism market, they can reemerge as suitable with their original features... In essence, dynamic tourism expects a future that calls for constant re-evaluation with attention paid to keeping existing items in the arena as tourism products". These new branded messages make clients explore new items otherwise ignored especially when they are within the easy reach of domestic tourists.

\section{Conclusion}

This paper brings to the fore the fact that the Kenyan tourism sector is operating below its potential largely as a result of the absence of tourism offices and information centers. This has hindered the gaining of important insights into the domestic market. Many other sectors of the economy have invested much in research while the Kenyan tourism industry is largely concentrated on regulating and licensing the industry players. Two years after the devolution of the local tourism function to the county governments, the script is still the same: lack of data on domestic tourism within the counties, and therefore no clear road map with regard to the development of domestic tourism. This, according to Boniface (2001, p.1), can be attributed to industry wide stagnation and immaturity as a result of "a blind eye turned by the industry to its own shortcomings; a lack of appreciation for the need and reasons for development; a failure of ideas and imaginations". Nevertheless, the domestic tourist needs to be understood and to be encouraged to travel. Such may include offering discounts and attractive packages to walk-in clients, developing clearly defined market segments, being aggressive in providing market information to the masses, making transport easily available, and encouraging a saving culture for holidays. Such policies would target different market segments, notably: corporate clientele, MICE (Meetings, Incentives, Conventions and Events) clientele, and family/holiday clientele.

There is also a need to undertake household surveys at a national scale, or with selected counties, to determine the real magnitude of domestic tourism in Kenya, distinguishing between excursionist and overnight stays.

\section{Bibliography}

Akama, J.S. "Tourism Development in Kenya: Problems and Policy Alternatives." Progress in Tourism and Hospitality Research 2 (1997); 95-105.

Boniface, P. Dynamic Tourism, Journeying with Change. Clevedon: Channel View Publications, 2001. 
Dieke, P.U.C. "Policies for Tourism Development in Kenya." Annals for Tourism Research 18 (1991): 269-294.

Finlay, L. \& C. Ballinger. Qualitative Research for Health Professionals: Challenging Choices. Chichester: John Wiley Publishers, 2006.

Government of Kenya. Kenya National Bureau of Statistics. Economic Survey. Nairobi, Kenya, 2014.

Government of Kenya. Kenya National Bureau of Statistics. Economic Survey. Nairobi, Kenya, 2012.

Government of Kenya. Kenya National Bureau of Statistics. Economic Survey. Nairobi, Kenya, 2010.

Kenya Institute of Public Policy Research and Analysis, (2009). Kenya Economic Report 2009, Building a Globally Competitive Economy. Nairobi: KIPPRA.

Kenya Tourism Federation, (2010). Newsletter.

Kieti, D., M.M. Okello, and B. Wishitemi. "Kenya's Domestic Tourism: Motivation, Development and Trends." In Le Kenya dans le $3^{e}$ Révolution Touristique: au-delà du safari, ed, J. Rieucau, 17-37. Paris: 1'Harmattan, 2014

Kihima, B.O. “Towards Unlocking Tourism Potential in Less Visited Destinations in Kenya: The case of Western Kenya Region.” PhD diss., University of Lyon 2, 2010.

Kihima, B.O. "Unlocking the Kenyan Tourism Potential through Park Branding Exercise." Tourism Recreation Research 39, no.1 (2014): 51-64.

Kihima, B.O. and E. Kimaru. "Kaya Kinondo Community Ecotourism Project in Kenya: A Decade Later." The Eastern African Journal of Hospitality, Leisure and Tourism 1, no.1 (2013): 12-24.

Kivuva, A., Kihima, B.O. and Nzioka A. "Selecting Non-Classified Hotels in Kenya: What Really Matters for Business Guests?” African Journal of Hospitality, Tourism and Leisure 3, no.2 (2014): 1-12.

Lilieholm, R.J. and L.R. Romney. "Tourism, National Parks and Wildlife." In Tourism and National Parks: Issues and Implications, eds, Butler, R. and S.W. Boyd, 137-151. Chichester: John Wiley and Sons ltd, 2000.

Odunga, P.O. "Choice of Attractions, Expenditure and Satisfaction of International Tourists to Kenya,.’PhD diss., Wagenigen University, 2005.

Okello, M.M., G.S. Manka and E.D. D’Amour. “The Relative Importance of Large Mammal Species for Tourism in Amboseli National Park, Kenya." Tourism Management, 29 (2008): 751-760. 
Pierret, F. "Some Points on Domestic Tourism." World Tourism Organization. 2011. Accessed August 20, 2014. www.unwto.org.

Sarantakos, S. Social Research. (4 ${ }^{\text {th }}$ ed.). New York: Palgrave Macmillan, 2013.

Sinclair, M.T. Tourism Development in Kenya. Nairobi: World Bank, 1990.

Sindiga, I. "Domestic Tourism in Kenya." Annals of Tourism Research, Vol. 23,1 (1996): 1931.

Wels, H. "Critical Reflection on Cultural Tourism in Africa: the Power of European Imagery." In Cultural Tourism in Africa: Strategies for the new Millennium, eds, Akama, J., and P. Sterry, Proceedings of the ATLAS Africa International Conference, Mombasa Kenya, 2000 .

World Bank Group. Kenya's Tourism: Polishing the Jewel. Finance and Private Sector Development, Africa Region Summary Report, 2010.

World Resource Institute; Department of Resource Surveys and Remote Sensing, Ministry of Environment and Natural Resources, Kenya; Central Bureau of Statistics, Ministry of Planning and National Development, Kenya; International Livestock Research Institute, (2007). Nature's Benefits in Kenya, An Atlas of Ecosystems and Human Well-Being, World Resources Institute, Washington, DC and Nairobi.

World Tourism Organization. Reference material 1: Initial Findings of UNWTO Study on Domestic Tourism across Asia and the Pacific: Item 5b of the Provisional Agenda. 2012. Accessed August 20, 2014. www.unwto.org .

Yuksel, A. "Writing Publishable Papers." Tourism Management 24 (2003): 437-446. 